\title{
Introduction: Archaeology and Philosophy
}

\author{
Anton Killin ${ }^{1} \cdot$ Sean Allen-Hermanson ${ }^{2}$
}

Published online: 18 March 2020

○) Springer Nature B.V. 2020

In recent years philosophers have become increasingly interested in topics at the intersection of philosophy, evolutionary theory, and archaeology - from cultural and cognitive evolution to naturalized metaphysics, to issues of inference, evidence, and methodology in archaeology. This Topoi special issue collects new work by philosophers, from a variety of career stages, on topics that span this area of attention.

The opening article, Kim Sterelny's "The Origins of Multi-level Society", begins by contrasting the "open" social organization of ethnographically known hominin forager groups and the "closed" organization of chimpanzees and bonobos. The puzzle Sterelny addresses is the transition from a closed organization to an open one in hominin evolutionary history. Assuming that the closed social worlds of chimpanzees and bonobos more closely resembles that of the Pan/Homo last common ancestor than does the open organization of behaviorally and psychologically modern humans, the ancestral hominin state was then one in which distrust and suspicion towards out-group hominins was the norm, which makes it difficult to see how an open society could originate. Two existing causal hypotheses concerning this transition are critically evaluated. These are Robert Layton's ecological model, according to which changes in hominin foraging practices triggered community expansion, then fractionation and changes in internal organization (Layton 2008; Layton and O'Hara 2010; Layton et al. 2012) and Bernard Chapais' kinship-based band-aggregation model (Chapais 2008, 2013, 2014). Sterelny combines aspects of each into a third, novel hypothesis: a Layton-style ecological theory of the initial formation of multi-level communities is

Anton Killin

akillin@mta.ca

Sean Allen-Hermanson

hermanso@fiu.edu

1 Department of Philosophy, Mount Allison University, Sackville, NB E4L 1G9, Canada

2 Department of Philosophy, Florida International University, Miami, FL 33199, USA supplemented with the posit of an expanded kin recognition repertoire- a proximate mechanism facilitating continued affiliation between individuals across nascent bands who interact less frequently. Finally, methodological challenges, including those imposed by the nature of archaeological and palaeoanthropological evidence, are reflected upon.

In "Behavioral Modernity in Retrospect", Stephen Davies considers another, more recent hominin transition puzzle: the origins of behaviorally and psychologically modern sapiens. Anatomically modern humans are currently thought to originate around 300,000 years ago, or even earlier (Hublin et al. 2017; Richter et al. 2017). Yet paradigmatic examples of evidence for behavioral/psychological modernity such as visual art and figurines, grave goods, and musical instruments do not appear in the archaeological record until much more recently. An explanation of this apparent gap is called for. Davies begins by reviewing the classic behavioral modernity thesis of the 1980s and 1990s, according to which modern minds were achieved in the Upper Palaeolithic " $c o g$ nitive revolution", "great leap forward", "creative explosion" of approximately 40,000 years ago (Pfeiffer 1982; Mellars and Stringer 1989; Diamond 1992). Plausibly, however, the above-mentioned paradigmatic examples do not exhaust the evidence for capacities associated with behavioral modernity such as symbolism, which appears to pre-date the Upper Palaeolithic technocomplex. In this vein, Davies marshals the counterevidence to the classic thesis and considers the relevance to the debate of practical reasoning and cooperation, evidence for tools and hunting, and arguments from absence of evidence. Davies concludes in favor of a gradualist conception of behavioral modernity (McBrearty and Brooks 2000), one which places the onset of behavioral modernity as early as 150,000 years ago, and explains an apparent revolution at a later date by appeal to the vagaries of preservation, sapiens population dynamics, and climatic instability.

Although often appealed to in discussions of behavioral modernity (and cognitive and cultural evolution generally), the notion of symbolic thought is vexed and often unclear, as Davies points out. Ronald J. Planer's article, "What is 
Symbolic Cognition?" addresses this very concern. Planer distinguishes and critically discusses several distinct notions of "symbolic cognition" and "symbol", in order to pave the way for clearer argumentation and analysis.

Cognitive archaeologists make and evaluate inferences about the minds of ancient hominins based on the material record and theory. According to Wynn and Coolidge (2004), Neanderthals were capable of long-term working memory. The idea is that artefacts produced by the Neanderthals- the Levallois toolkit—are the outcomes of complex production sequences that, according to a cognitive theory which combines Ericsson and colleagues' cue-structure model (Ericsson and Kintsch 1995; Ericsson and Delaney 1999; Ericsson et al. 2000) with Keller and Keller's (1996) skill acquisition model, required long-term working memory. This kind of inference has been characterized as a minimal capacity inference (Currie and Killin 2019): such an inference takes us from an archaeological trace, via a cognitive theory, to the existence of some cognitive capacity. Ross Pain characterizes a closely related inference-cognitive transition inference-in his article "What Can the Lithic Record Tell Us About the Evolution of Hominin Cognition?".

A cognitive transition inference takes us from archaeological traces, via a cognitive theory, to the evolution of some cognitive capacity. It does so by establishing that technologies at time $t$ do not require some minimal capacity for their production or use (according to some cognitive theory), and that technologies at time $t+n$ do, positing a cognitive upgrade which accounts for the emergence of the novel cognitive capacity signaled by the latter technologies. Pain takes Coolidge and Wynn's work on behavioral modernity as a case study (Coolidge and Wynn 2018), contrasting their "innate-cognition first" hypothesis with demographic and environmental explanations, and concluding that a plausible line of reasoning leads us to a dilemma. On the first horn of the dilemma, cognitive transition inferences are undermined; on the second, the causal role of demographic and environmental features are underestimated. Neither horn appears to have much to recommend it. In gesturing towards a provisional solution to the dilemma, Pain points out that multiple lines of evidence and causal-association inference (Currie and Killin 2019) may help to constrain the hypothesis space, and he avails himself of the resources of Waters' causal difference-making framework (Waters 2007).

Anton Killin's "Music Pluralism, Music Realism, and Music Archaeology" applies Adrian Currie's argument for realism about species (see Currie 2016) to the case of music. Killin's article begins by first motivating conceptual pluralism about music and then sketching an influential line of reasoning that infers ontological eliminativism about a category to which a pluralistic concept pertains (Ereshefsky 1992, 1998). To block the move from music pluralism to music eliminativism, Killin's article makes a case for a Currie-style indifference realism about music. The indifference realist claims that when a legitimate research program is indifferent (in a vindicatory sense) to a plurality of legitimate, nonequivalent concepts pertaining to some ontological category, realism about the general category is licensed. Thus this strategy receives its justification (at least partially) from naturalized metaphysics, according to which metaphysical claims are provisional hypotheses to be settled in large part by empirical research and reflection on empirical research. Currie's argument for indifference realism about species by way of palaeobiological methodology provides an analogy. Killin's music case study focuses on the archaeological research centered on the question of Neanderthal musicality and in particular the musical status of the Divje babe I "Neanderthal flute".

Next, we shift from music to language. In "The Case Against Linguistic Palaeontology", Fintan Mallory considers the method of inference about past cultures from reconstructed languages, its controversial status in some archaeological circles, and the debate between its advocates and critics. Mallory argues that the case against this method is overstated, encouraging archaeologists to make use of it where appropriate, and providing a case study of the Indo-European homeland problem (see, e.g., Renfrew 1987; Pereltsvaig and Lewis 2015) as an example. As with Davies' article, among the considerations evaluated are arguments from absence of evidence. Mallory concludes by motivating a research program in linguistic palaeontology that is in direct discussion with analytic philosophy of language, which has heretofore been largely ignored in palaeolinguistics.

Finally, Stephen M. Downes' article, "The Role of Ancient DNA Research in Archaeology" confronts an increasing tendency to see genetic evidence as the principal arbiter of archaeological debates (Reich 2018). Utilizing Alison Wylie's framework and notion of "trading zones" (e.g., Chapman and Wylie 2016; Wylie 2000), Downes argues that although ancient DNA techniques are an important tool for generating knowledge about our evolutionary past, archaeological debate comprises a much wider range of core controversies, of which many cannot obviously be settled by techniques from molecular population genetics. Downes makes the case for a more "epistemically respectful" interdisciplinary practice than that which appears to be adopted by some researchers.

Acknowledgements We thank the authors for their contributions and the many referees who gave their time and critical attention. We're grateful to Marilynn Johnson for assistance in the early stages of this special issue and to Ellen Clarke for acting as sub-editor. Ganesh Jagadeesan at Springer provided helpful editorial assistance. Allan Wesler provided a generous donation to Florida International University which enabled Johnson, Killin, and Allen-Hermanson to embark on 
a year-long research project on philosophy of archaeology. This special issue is one output of that project.

\section{References}

Chapais B (2008) Primeval kinship. Harvard University Press, Cambridge

Chapais B (2013) Monogamy, strongly bonded groups and the evolution of human social structure. Evol Anthropol 22:52-65

Chapais B (2014) Complex kinship patterns as evolutionary constructions, and the origins of sociocultural universals. Curr Anthropol 55(6):751-783

Chapman R, Wylie A (2016) Evidential reasoning in archaeology. Bloomsbury, London

Coolidge FL, Wynn T (2018) The rise of Homo sapiens: the evolution of modern thinking, 2nd edn. Oxford University Press, Oxford

Currie A (2016) The mystery of the Triceratops's mother: how to be a realist about the species category. Erkenntnis 81:795-816

Currie A, Killin A (2019) From things to thinking: cognitive archaeology. Mind Lang 34:263-279

Davies S (2019) Behavioral modernity in retrospect. Topoi. https://doi. org/10.1007/s11245-019-09671-4

Diamond J (1992) The third chimpanzee: the evolution and future of the human animal. Harper Collins, New York

Downes SM (2019) The role of ancient DNA research in archaeology. Topoi. https://doi.org/10.1007/s11245-019-09665-2

Ereshefsky M (1992) Eliminative pluralism. Philos Sci 59:671-690

Ereshefsky M (1998) Species pluralism and anti-realism. Philos Sci 65:103-120

Ericsson KA, Delaney PF (1999) Long-term working memory as an alternative to capacity models of working memory in everyday skilled performance. In: Ericsson KA, Delaney PF (eds) Models of working memory: mechanisms of active maintenance and executive control. Cambridge University Press, New York, pp 257-297

Ericsson KA, Kintsch W (1995) Long-term working memory. Psychol Rev 102(2):211-245

Ericsson KA, Patel V, Kintsch W (2000) How experts' adaptations to representative task demands account for the expertise effect in memory recall: comment on Vicente and Wang. Psychol Rev 107(3):578-592

Hublin J-J, Ben-Ncer A et al (2017) New fossils from Jebel Irhoud, Morocco and the pan-African origin of Homo sapiens. Nature 546:289-292

Keller CM, Keller JD (1996) Cognition and tool use: the blacksmith at work. Cambridge University Press, Cambridge

Killin A (2019) Music pluralism, music realism, and music archaeology. Topoi. https://doi.org/10.1007/s11245-019-09676-z
Layton R (2008) What can ethnography tell us about human social evolution? In: Allen N, Callan H, Dunbar R, James W (eds) Early human kinship: from sex to social reproduction. Blackwell, Oxford, pp 113-128

Layton R, O'Hara S (2010) Human social evolution: a comparison of hunter-gatherer and chimpanzee social organisation. In: Dunbar R, Gamble C, Gowlett J (eds) Social brain, distributed mind. Oxford University Press, Oxford, pp 83-113

Layton R, O'Hara S, Bilsborough A (2012) Antiquity and social function of multilevel social organisation among human hunter-gatherers. Int J Primatol 33:1215-1245

Mallory F (2020) The case against linguistic palaeontology. Topoi. https://doi.org/10.1007/s11245-020-09691-5

McBrearty S, Brooks AS (2000) The revolution that wasn't: a new interpretation of the origin of modern humans. J Hum Evol 39:453-563

Mellars P, Stringer C (eds) (1989) The human revolution: behavioural and biological perspectives on the origins of modern humans. Edinburgh University Press, Edinburgh

Pain R (2019) What can the lithic record tell us about the evolution of hominin cognition? Topoi. https://doi.org/10.1007/s11245-01909683-0

Pereltsvaig A, Lewis MW (2015) The Indo-European controversy. Cambridge University Press, Cambridge

Pfeiffer JE (1982) The creative explosion: an inquiry into the origins of art and religion. Harper and Row, New York

Planer RJ (2019) What is symbolic cognition? Topoi. https://doi. org/10.1007/s11245-019-09670-5

Reich D (2018) Who we are and how we got here: ancient DNA revolution and the new science of the human past. Pantheon, New York

Renfrew C (1987) Archaeology and language: the puzzle of IndoEuropean origins. Jonathan Cape, London

Richter D, Grün R et al (2017) The age of the hominin fossils from Jebel Irhoud, Morocco, and the origins of the Middle Stone Age. Nature 546:293-296

Sterelny K (2019) The origins of multi-level society. Topoi. https://doi. org/10.1007/s11245-019-09666-1

Waters CK (2007) Causes that make a difference. J Philos 104:551-579

Wylie A (2000) Questions of evidence, legitimacy, and the (dis)unity of science. Am Antiq 65(2):227-237

Wynn T, Coolidge FL (2004) The expert Neanderthal mind. J Hum Evol 46(4):467-487

Publisher's Note Springer Nature remains neutral with regard to jurisdictional claims in published maps and institutional affiliations. 